\title{
Agrochemical Properties of Leached Chernozem and Productivity of Grain Crops under the Influence of Fertilizers And Lime in Conditions of Trans- Urals
}

\author{
Aleksey M. Plotnikov, Andrey V. Sozinov, Igor V. Sinyavskiy \\ Kurgan State Agricultural Academy named after T.S. Maltsev \\ Lesnikovo village, Russia \\ E-mail: zem.ksaa@mail.ru
}

\begin{abstract}
Application of fertilizers in grain fallow rotation in the central part of Kurgan region increased the productivity of grain crops by 3.0-22.1\% and enhanced the quality of grain as well. The application of lime affected the composition of SAC and acidity of chernozem. Combined application of lime and sapropel reduced the hydrolytic acidity of leached chernozem by $1.2 \mathrm{~mol}$. equiv. $/ 100 \mathrm{~g}$ of soil and increased base saturation from $81.1 \%$ to $88.2 \%$
\end{abstract}

Keywords-productivity, grain crops, acidity, sapropel, lime, leached chernozem, nitrogen-phosphate fertilizers

\section{INTRODUCTION}

Preservation and improvement of the fertility of arable soil is the main problem of modern arable farming. The prolonged exploitation of arable soil with increased intensification of farming system is known to affect soil forming. Over the recent years, low volumes of organic and mineral fertilizers, as well as chemical ameliorants have led to substantial reduction in effective fertility of chernozems.

Single-sided application of mineral or organic fertilizers cannot facilitate high an stable productivity of agrocoenosis. Having limited amount of manure for replenishing organic matter in soil, hay and afterharvest of grain crops, green fertilizer, etc. should be used more. As a source of organic matter lacustrine sapropel can be used. This fertilizer contains a complex of organic and mineral substances, compounds of nitrogen, sulfur, copper, boron, molybdenum and other microelements. Application of sapropel improves agricultural crop capacity and has positive impact on agrochemical and hydrophysical soil properties [1-6]. Field experiments have proven the reasonability of sapropel application in Siberia [7], Chelyabinsk [8], Tyumen [9], Kurgan regions [14, 15] and in the conditions of North Kazakhstan [10].

In Russia, the explored reserves of sapropel amount to 45 bln $\mathrm{m}^{3}$. Only in Kurgan region, the territorial balance accounts for 118 lacustrine sapropel deposits. The total area of sapropel sediments in the region amounts to 15.6 ha with geological reserves of $133 \mathrm{mln}$ tons [4].

The work is aimed at studying the impact of lacustrine sapropel in combination with lime and nitrogen-phosphorus fertilizers on harvest and quality of grain crops, soil properties under grain fallow rotation in forest steppe zone of Kurgan region.

\section{INVESTIGATION METHODS}

The studies took place in 2014-2016 on the test field of Kurgan SAA. The soil of the test field is represented by slightly humic and slightly loamy leached chernozem; the percentage of fractions less than $0.01 \mathrm{~mm}$ in horizon Ap amounted to $22.4 \%$, humus content was $3.32 \%$, cation exchange capacity was 20.5 $\mathrm{mmol} / 100 \mathrm{~g}$ of soil, base saturation was $80.8 \%$, $\mathrm{pH}$ of the salt extract was 5.24 , bulk density was $1.15 \mathrm{~g} / \mathrm{cm}^{3}$, solid phase density was $2.61 \mathrm{~g} / \mathrm{cm}^{3}$, total porosity was $55.9 \%$, wilting moisture was $7.0 \%$, content of labile phosphorus was 119 $\mathrm{mg} / \mathrm{kg}$, content of exchange potassium was $148 \mathrm{mg} / \mathrm{kg}$, the thickness of horizons $\mathrm{Ap}+\mathrm{AB}$ was $36 \mathrm{~cm}$.

The crop rotation is four-year rotation: fallow - summer wheat - summer wheat - barley. The field stationary experiment had four replications.

The variants in replications were located randomly. The replications were arranged in four levels. The total area of the plot was $15 \mathrm{~m}^{2}$, the record plot was $12 \mathrm{~m}^{2}$ (2 $\left.\mathrm{m} \times 6 \mathrm{~m}\right)$. Sapropel and lime were introduced during presowing cultivation with incorporation to the depth of $10-12 \mathrm{~cm}$.

The experiment scheme was a matrix of fully factorial threefactor experiment and included 12 variants. Factor A - lime $\left(\mathrm{CaCO}_{3}\right)(0$ and $2.0 \mathrm{t} /$ ha to neutralize $1 / 2$ of hydrolytic acidity). Factor B - yearly introduction of mineral fertilizers $(0$ and N30P30). Factor C - sapropel (0 and $20 \mathrm{t} / \mathrm{ha})$. The experiment implemented sapropels from Kurgan (no. 1) and Sverdlovsk (no. 2) regions. The sapropels had the following characteristics: sapropel no. $1-\mathrm{pH}-7.76$; ash $-29.8 \%$; $\mathrm{N}-7.05 \% ; \mathrm{P}_{2} \mathrm{O}_{5}-$ $0.53 \% ; \mathrm{K}_{2} \mathrm{O}-0.23 \% ; \mathrm{CaO}-47.8 \%$, sapropel no. 2 - pH - 4.40; ash $-55.6 \% ; \mathrm{N}-4.11 \% ; \mathrm{P}_{2} \mathrm{O}_{5}-0.41 \% ; \mathrm{K}_{2} \mathrm{O}-0.40 \% ; \mathrm{CaO}-$ $23.2 \%$. The chemical ameliorant used in the experiment was represented by lime dust $\left(\mathrm{CaCO}_{3}-85 \%\right.$, moisture is $1.2 \%$, content of inactive particles is $1.5 \%$ ). Hydrolytic acidity at the 
moment of experiment initiation was $3.81 \mathrm{mmol} / 100 \mathrm{~g}$ of soil. The mineral fertilizers were represented by ammonium nitrate, nitrogen-phosphorus mixed fertilizer, $\left(\mathrm{N}_{\mathrm{aa}}-34.6 \%\right.$ of active substance) and normal superphosphate $\left(\mathrm{P}_{\mathrm{sg}}-26 \%\right.$ of active substance) were broadcast annually before the seeding according to the experiment scheme.

The seeded crops were Zhigulyovskaya wheat and Preria barley with seeding rate of $5.0 \mathrm{mln}$ of fertile grains per hectare.

The seeding in 2014 was on the 1st of June by APP-7,2 seeding machine; the harvesting was at the firm ripe stage on 10th of October; in 2015, the seeding was on the 2nd of June, the harvesting on 10th of September; in 2016, the seeding was on 30th of May, the harvesting was on 25th of August.

The gather was accounted manually from each plot and after weighting it was expressed per 1 ha under standard moisture and $100 \%$ purity.

The soil samples were taken from the plow layer after harvesting. The hydrolytic acidity of soil was determined by Kappen's method (GOST 26483-85); the exchange acidity was determined by potentiometric method; the content of exchange calcium and magnesium cations were determined by $1 \mathrm{~N}$ extract of $\mathrm{NaCl}$ by trilonometric titrimetry [11]. Crude gluten was determined by washing as per GOST 13586.1-68, grain-unit as per GOST 10840-64, mass of 1000 grains as per GOST 1084289.

The statistical processing of the gather results was made by the method of dispersion analysis of a three-factor experiment, and linear correlation of B.A. Dospekhov [12]. To reveal the dependence of barley yield on the agrochemical characteristics of the soil, non-linear multiple correlation-regression analysis in Statistica 10.0 software was used.

The technology of grain crops cultivation and implemented doses of fertilizers corresponded to those recommended for our zone [13].

The weather conditions during vegetation period in 2014 were adverse: the beginning of plant development was characterized by high temperature, absence of precipitation and drought until the end of June $\left(\mathrm{HTI}_{\mathrm{June}}\right.$ was 0.31$)$. Then, during three weeks, there were low air temperature and abundant precipitation of various intensity. July was the coldest and most moist month from 1893; the amount of precipitation was 141.6 $\mathrm{mm}$, while the norm is $60 \mathrm{~mm}$. August was close to long-term average annual indicators; however, precipitation was very nonuniform: 3 days in the beginning and the end of the month in the amount of 14-22 mm (HTI August $_{\text {was } 1.13) \text {. September }}$ was cold and almost completely dry in the second and last thirds.

Weather conditions of 2015 can be characterized as favorable: increased precipitation and high temperature were during the first month of wheat development. June was drought: the temperature was higher by 3.7 degrees, while the amount of precipitation was less by $34.9 \mathrm{~mm}$, as compared to long-term average annual data. The temperature in July was lower than long-term average annual values (by $1.7^{\circ} \mathrm{C}$ ) with nonuniform precipitation, because the most part of it $(68 \%)$ was in the first third of the month. The temperature in August was close to that of July, while the major part of precipitation was in the last third of the month and amounted to $58 \%$ of all precipitation in the month.

Weather conditions of the vegetation period of 2016 can be considered as mainly favorable for barley. In certain periods there was abundant precipitation. In May, average air temperature was higher by $0.4{ }^{\circ} \mathrm{C}$, while the precipitation amount was $43 \%$ of long-term average annual values. The air temperature and total precipitation in June were comparable to long-term average annual values. In July, the temperature was close to long-term average annual values, while the total precipitation amounted to $132 \mathrm{~mm}$ or $220 \%$ of typical amount. Especially abundant precipitation was in the second third of the month: $61 \mathrm{~mm}$ with the long-term average annual amount of 18 $\mathrm{mm}$. August was characterized by increased long-term average annual temperature by $4.9^{\circ} \mathrm{C}$ and negligible precipitation amount of $2 \mathrm{~mm}$ ( $4.3 \%$ of typical value).

\section{RESULTS AND DISCUSSION}

In 2014 the wheat gather without fertilizers amounted to $1.68 \mathrm{t} / \mathrm{ha}$. Introduction of nitrogen-phosphorus fertilizers maximized the yield up to $2.03 \mathrm{t} /$ ha (Table 1 ) when the average figures in Kurgan region were 1.46-1.54 t/ha.

The liming of the soil had no remarkable effect on the wheat yield in the first year of the experiment. Implementation of sapropels appreciably increased wheat yield as compared to the reference data: by $0.14-0.19 \mathrm{t} / \mathrm{ha}\left(\mathrm{LSD}_{0.95}\right.$ for $\mathrm{C}$-factor $\left.=0.08\right)$ $[14,15]$.

In 2015 the wheat yield with natural mineral nutrition was $1.44 \mathrm{t} / \mathrm{ha}$; after mineral fertilization it increased to $1.54 \mathrm{t} /$ ha with substantial increase $\left(\mathrm{LSD}_{0.95}=0.06\right)$. The largest crop yield was in 2015 when all additives were combined: lime, sapropel and mineral fertilizers; it amounted to $1.80 \mathrm{t} / \mathrm{ha}$.

Over these two years of grain fallow rotation, average reference yield of summer wheat was $1.56 \mathrm{t} / \mathrm{ha}$. The effect and aftereffect of sapropel have increased the wheat yield up to 1.65-1.68 t/ha. The largest crop yield (1.91 t/ha) was demonstrated by the variant with sapropel 1 with background of lime and mineral fertilizers.

In 2016, the barley yield on the variant without fertilizers was $2.13 \mathrm{t} / \mathrm{ha}$; after introduction of mineral fertilizers it increased up to $2.56 \mathrm{t} / \mathrm{ha}$, after lime up to $2.20 \mathrm{t} / \mathrm{ha}$. The largest barley yield in the experiment $(2.64 \mathrm{t} / \mathrm{ha})$ was noted for the variant with combined implementation of sapropel and mineral fertilizers. The effect of sapropel, lime and mineral fertilizers substantially increases barley yield.

Total productivity of the crop rotation on the reference variant amounted to $5.25 \mathrm{t} / \mathrm{ha} \mathrm{g}$. $\mathrm{u}$. (1.75 t/ha annually), while with mineral fertilization $6.13 \mathrm{t} / \mathrm{ha}$ g.u. The largest productivity was provided by the variant with lime background with sapropel 2 and mineral fertilizers where the yield rose up to 6.41 
t/ha g.u., which is $1.16 \mathrm{t} / \mathrm{ha}(22 \%)$ more than that of reference.

TABLE 1. CROP CAPACITY OF GRAIN CROPS AND PRODUCTIVITY OF GRAIN FALLOW ROTATION USING FERTILIZERS, GRAIN UNITS T/HA (2014-2016)

\begin{tabular}{|c|c|c|c|c|c|c|c|}
\hline \multirow[t]{2}{*}{ Variant } & \multicolumn{2}{|c|}{ Summer wheat } & \multirow{2}{*}{$\begin{array}{r}\text { Barley } \\
2016 \\
\end{array}$} & \multirow{2}{*}{ Average yield } & \multirow{2}{*}{$\begin{array}{l}\text { Total gather of } \\
\text { grain units }\end{array}$} & \multicolumn{2}{|c|}{$\begin{array}{l}\text { Deviation from } \\
\text { reference data }\end{array}$} \\
\hline & 2014 & 2015 & & & & [t/ha] & [\%] \\
\hline 1. No fertilizers (reference) & 1.68 & 1.44 & 2.13 & 1.75 & 5.25 & - & - \\
\hline 2. Sapropel 1, $20 \mathrm{t} / \mathrm{ha}$ & 1.87 & 1.49 & 2.23 & 1.86 & 5.59 & 0.34 & 6 \\
\hline 3. Sapropel 2, $20 \mathrm{t} / \mathrm{ha}$ & 1.82 & 1.48 & 2.06 & 1.79 & 5.36 & 0.11 & 3 \\
\hline 4. N30P30 & 2.03 & 1.54 & 2.56 & 2.04 & 6.13 & 0.88 & 17 \\
\hline 5. N30P30 + Sapropel 1, 20 t/ha & 1.91 & 1.70 & 2.64 & 2.08 & 6.25 & 1.00 & 19 \\
\hline 6. N30P30 + sapropel 2, $20 \mathrm{t} / \mathrm{ha}$ & 1.93 & 1.63 & 2.61 & 2.06 & 6.17 & 0.92 & 18 \\
\hline 7. Lime, 2 t/ha - background & 1.76 & 1.49 & 2.20 & 1.82 & 5.45 & 0.20 & 4 \\
\hline 8. Background + sapropel 1, 20 t/ha & 1.98 & 1.56 & 2.37 & 1.97 & 5.91 & 0.66 & 13 \\
\hline 9. Background + sapropel 2, 20 t/ha & 1.86 & 1.52 & 2.33 & 1.90 & 5.71 & 0.46 & 9 \\
\hline 10 Background + N30P30 & 1.91 & 1.68 & 2.62 & 2.07 & 6.21 & 0.96 & 18 \\
\hline 11. Background + N30P30 + sapropel 1, 20 t/ha & 2.01 & 1.80 & 2.60 & 2.14 & 6.41 & 1.16 & 22 \\
\hline 12. Background + N30P30 + sapropel 2, 20 t/ha & 1.91 & 1.72 & 2.59 & 2.07 & 6.22 & 0.97 & 18 \\
\hline & \multirow{2}{*}{\multicolumn{3}{|c|}{ For partial differences }} & $\mathrm{LSD}_{0.95}$ & $\mathrm{LSD}_{0.95}$ & \multicolumn{2}{|l|}{$\mathrm{LSD}_{0.95}$} \\
\hline & & & & 0.16 & 0.14 & \multicolumn{2}{|c|}{0.12} \\
\hline & \multicolumn{3}{|c|}{ For factor A (lime) } & $\mathrm{P}>0.05$ & 0.06 & \multicolumn{2}{|l|}{0.05} \\
\hline & \multicolumn{3}{|c|}{ For factor B (mineral fertilizers) } & 0.06 & 0.06 & \multicolumn{2}{|l|}{0.05} \\
\hline & \multicolumn{3}{|c|}{ For factor C (sapropel) } & 0.08 & 0.07 & \multicolumn{2}{|l|}{0.06} \\
\hline & \multicolumn{3}{|c|}{ For $\mathrm{AB}$ interaction } & $\mathrm{P}>0.05$ & $\mathrm{P}>0.05$ & \multicolumn{2}{|l|}{0.07} \\
\hline & \multicolumn{3}{|c|}{ For $\mathrm{AC}$ interaction } & $\mathrm{P}>0.05$ & $\mathrm{P}>0.05$ & \multirow{2}{*}{\multicolumn{2}{|c|}{$\begin{array}{l}\mathrm{P}>0.05 \\
\mathrm{P}>0.05\end{array}$}} \\
\hline & \multicolumn{3}{|c|}{ For $\mathrm{BC}$ interaction } & 0.11 & $\mathrm{P}>0.05$ & & \\
\hline
\end{tabular}

The content of crude gluten in wheat grains on the variant without fertilizing in the first year of the experiment amounted to $29.5 \%$. The introduction of nitrogen-phosphorus fertilizers decreased the content down to $27.6 \%$, on the lime background down to $27.2 \%$. The maximum content of crude gluten $(34.6 \%)$ was noted for the variant combining all the three experimental factors. Sapropel 1 has increased the quality of wheat grain on the variants without ameliorant; consequently, the increase of gluten in the grain amounted to $4.5-4.9 \%$. In 2015, the content of gluten on the reference variant amounted to $20.8 \%$, while the application of mineral fertilizers has increased this indicator up to $21.3 \%$.

Over the two years of the experiment, the average content of gluten in wheat grain on the variant without fertilizers equals $25.2 \%$ (Table 2 ).

TABLE 2. CONTENT OF CRUDE GLUTEN IN SUMMER WHEAT GRAINS AFTER USING DIFFERENT FERTILIZERS, \% (2014-2015)

\begin{tabular}{|l|c|c|c|c|c|c|}
\hline \multirow{2}{*}{ Variant } & \multicolumn{3}{|c|}{ Without lime } & \multicolumn{3}{c|}{ Lime 2.0 t/ha } \\
\cline { 2 - 7 } & $\mathbf{2 0 1 4}$ & $\mathbf{2 0 1 5}$ & $\begin{array}{c}\text { average } \\
\text { over two } \\
\text { years }\end{array}$ & $\mathbf{2 0 1 4}$ & $\mathbf{2 0 1 5}$ & $\begin{array}{c}\text { average } \\
\text { over two } \\
\text { years }\end{array}$ \\
\hline $\begin{array}{l}\text { 1. No fertilizers } \\
\text { (reference) }\end{array}$ & 29.5 & 20.8 & 25.2 & 32.6 & 22.6 & 27.6 \\
\hline $\begin{array}{l}\text { 2. Sapropel 1, 20 } \\
\text { t/ha }\end{array}$ & 34.4 & 20.3 & 27.4 & 29.5 & 21.4 & 25.5 \\
\hline $\begin{array}{l}\text { 3. Sapropel 2, 20 } \\
\text { t/ha }\end{array}$ & 28.5 & 21.1 & 24.8 & 34.6 & 22.0 & 28.3 \\
\hline 4. N30P30 & 27.6 & 21.3 & 24.5 & 27.2 & 22.2 & 24.7 \\
\hline $\begin{array}{l}\text { 5. N30P30+ } \\
\text { sapropel 1, 20 t/ha }\end{array}$ & 34.0 & 23.4 & 28.7 & 29.1 & 23.0 & 26.1 \\
\hline $\begin{array}{l}\text { 6. N30P30+ } \\
\text { sapropel 2, 20 t/ha }\end{array}$ & 33.7 & 22.2 & 28.0 & 27.7 & 22.9 & 25.3 \\
\hline
\end{tabular}

In 2014 , the mass of 1000 wheat grains from the variant without fertilizers amounted to $30.4 \mathrm{~g}$; after introduction of mineral fertilizers, it increased up to $33.4 \mathrm{~g}$ (Table 3 ). The application of sapropel increased the mass of 1000 grains by $0.1-2.7 \mathrm{~g}$, application of lime by $0.5 \mathrm{~g}$. The correlation analysis has shown that increased mass of 1000 grains conditioned the growth of the wheat yield, we have noted direct average dependence between these indicators $\left(\mathrm{r}_{0.95}=0.63-0.89\right)$. In 2015 , the largest value of this indicator was noted for the variant sapropel 1+N30P30 (35.1 g). In 2016, the mass of 1000 barley grains without fertilization amounted to $44.2 \mathrm{~g}$, with mineral fertilizers it increased up to $46.5 \mathrm{~g}$; the aftereffect of sapropel and lime also increased the mass of 1000 barley grains. The increased mass of 1000 grains on the variants with organic and mineral fertilizers amounted to $1.9-2.2 \mathrm{~g}$, as compared to the reference variant; the variants with combined application of lime, the increase of the mass of 1000 grains amounted to 2.6$2.9 \mathrm{~g}$.

The grain-unit of wheat in 2014 on the reference variant amounted to $639 \mathrm{~g} / \mathrm{l}$; maximum of this indicator $(661 \mathrm{~g} / \mathrm{l})$ was noted on the variant with introduction of N30P30. In 2015, the largest grain-unit $(710 \mathrm{~g} / \mathrm{l})$ was noted for the variant with aftereffect of sapropel and lime. The barley grain-unit varied with application of fertilizers as compared to the variant without fertilizers. This indicator has increased on the variant with mineral fertilizers by $14 \mathrm{~g} / \mathrm{l}$, on the variants with sapropel and lime by $9-22 \mathrm{~g} / \mathrm{l}$. 
TABLE 3. QUALITATIVE CHARACTERISTICS OF GRAIN CROPS USING FERTILIZERS (TEST FIELD OF KURGAN SAA, 2014-2016)

\begin{tabular}{|l|c|c|c|c|c|c|}
\hline \multirow{2}{*}{ Variant } & \multicolumn{3}{|c|}{$\begin{array}{c}\text { Mass of 1000 } \\
\text { grains [g] }\end{array}$} & \multicolumn{2}{c|}{ Grain-unit [g/l] } \\
\cline { 2 - 8 } & $\mathbf{2 0 1 4}$ & $\mathbf{2 0 1 5}$ & $\mathbf{2 0 1 6}$ & $\mathbf{2 0 1 4}$ & $\mathbf{2 0 1 5}$ & $\mathbf{2 0 1 6}$ \\
\hline 1. No fertilizers (reference) & 30.4 & 33.0 & 44.2 & 639 & 692 & 569 \\
\hline 2. Sapropel 1, 20 t/ha & 33.1 & 33.3 & 45.3 & 651 & 693 & 584 \\
\hline 3. Sapropel 2, 20 t/ha & 30.5 & 33.2 & 44.0 & 645 & 693 & 571 \\
\hline 4. N30P30 & 33.4 & 33.6 & 46.5 & 661 & 708 & 583 \\
\hline 5. N30P30+ sapropel 1, 20 t/ha & 32.3 & 35.1 & 46.4 & 648 & 708 & 580 \\
\hline 6. N30P30+ sapropel 2, 20 t/ha & 30.3 & 34.5 & 46.1 & 642 & 709 & 583 \\
\hline 7. Lime, 2 t/ha - background & 30.9 & 33.1 & 44.0 & 634 & 688 & 574 \\
\hline $\begin{array}{l}\text { 8. Background + sapropel 1, 20 } \\
\text { t/ha }\end{array}$ & 33.3 & 33.2 & 45.4 & 657 & 710 & 578 \\
\hline $\begin{array}{l}\text { 9. Background + sapropel 2, 20 } \\
\text { t/ha }\end{array}$ & 31.3 & 34.1 & 46.6 & 652 & 706 & 591 \\
\hline 10 Background + N30P30 & 31.9 & 33.9 & 47.0 & 636 & 704 & 578 \\
\hline $\begin{array}{l}\text { 11. Background + N30P30+ } \\
\text { sapropel 1, 20 t/ha }\end{array}$ & 32.6 & 34.0 & 47.1 & 643 & 705 & 574 \\
\hline $\begin{array}{l}\text { 12. Background + N30P30+ } \\
\text { sapropel 2, 20 t/ha }\end{array}$ & 32.0 & 33.6 & 46.8 & 638 & 708 & 585 \\
\hline $\begin{array}{l}\text { Coefficient of correlation with } \\
\text { crop yield r } 0.95\end{array}$ & 0.71 & 0.63 & 0.89 & - & - & - \\
\hline
\end{tabular}

The optimal $\mathrm{pH}$ of soil solution and the saturation of the soil absorbing complex by bases are obligatory conditions of modern arable farming systems with continuous objective process of soil depletion by bases due to their removal with gathered crops [13].

By the end of crop rotation, in the unfertilized variant, the sum of exchange cations of calcium and magnesium amounted to $16.3 \mathrm{mmol} / 100 \mathrm{~g}$ of soil. The cation exchange capacity (CEC) reached $20.1 \mathrm{mmol} / 10 \mathrm{~g}$ of soil, while the base saturation $(\mathrm{V})$ was $81.1 \%$ (Table 4).

TABLE 4. IMPACT OF ORGANIC AND MINERAL FERTILIZERS ON SOIL ACIDITY AND COMPOSITION OF SAC (TEST FIELD OF KURGAN SAA, 2016)

\begin{tabular}{|c|c|c|c|c|c|c|c|}
\hline \multirow{2}{*}{ Variant } & $\mathrm{Ca}^{2+}$ & $\mathrm{Mg}^{2+}$ & $\mathbf{H}^{+}$ & CEC & \multirow{2}{*}{$\mathbf{V}[\%]$} & \multirow{2}{*}{$\mathrm{pH}_{\mathrm{H} 2 \mathrm{O}}$} & \multirow{2}{*}{$\mathbf{p H}_{\mathrm{KCl}}$} \\
\hline & \multicolumn{4}{|c|}{$\mathrm{mmol} / 100 \mathrm{~g}$ of soil } & & & \\
\hline 1. No fertilizers (reference) & 11.5 & 4.8 & 3.82 & 20.1 & 81.1 & 6.38 & 5.21 \\
\hline 2. Sapropel 1, $20 \mathrm{t} / \mathrm{ha}$ & 12.0 & 5.2 & 3.85 & 21.1 & 81.5 & 6.36 & 5.24 \\
\hline 3. Sapropel 2, $20 \mathrm{t} / \mathrm{ha}$ & 11.9 & 5.1 & 4.17 & 21.2 & 80.2 & 6.26 & 5.14 \\
\hline 4. N30P30 & 11.2 & 4.5 & 4.30 & 20.0 & 78.5 & 6.23 & 5.06 \\
\hline 5. N30P30+ sapropel 1, 20 t/ha & 12.0 & 4.8 & 4.19 & 21.0 & 80.0 & 6.18 & 5.09 \\
\hline 6. N30P30+ sapropel 2, 20 t/ha & 11.7 & 4.5 & 4.41 & 20.6 & 78.6 & 6.05 & 4.96 \\
\hline 7. Lime, $2 \mathrm{t} /$ ha - background & 13.4 & 5.3 & 3.31 & 22.0 & 85.0 & 6.54 & 5.52 \\
\hline 8. Background + sapropel 1, $20 \mathrm{t} / \mathrm{ha}$ & 14.4 & 5.1 & 2.62 & 22.1 & 88.2 & 6.98 & 6.00 \\
\hline 9. Background + sapropel $2,20 \mathrm{t} / \mathrm{ha}$ & 13.7 & 4.9 & 3.32 & 21.9 & 84.9 & 6.74 & 5.54 \\
\hline 10 Background + N30P30 & 12.8 & 4.8 & 3.04 & 20.6 & 85.4 & 6.92 & 5.65 \\
\hline 11. Background + N30P30+ sapropel 1, 20 t/ha & 13.9 & 5.2 & 3.07 & 22.2 & 86.4 & 6.70 & 5.45 \\
\hline 12. Background + N30P30+ sapropel 2, 20 t/ha & 13.5 & 5.1 & 3.55 & 22.2 & 83.8 & 6.58 & 5.42 \\
\hline
\end{tabular}

The experimental data confirmed the literature data about mineral fertilizers promoting calcium removal from soil absorbing complex into solution increasing its lability. In our investigation, the mineral fertilization has decreased the soil base saturation by $2.6 \%$.

The introduction of organic fertilizers increased CEC up to $21.2 \mathrm{mmol} / 100 \mathrm{~g}$ of soil. By the end of crop rotation, the limed variants demonstrated active saturation of soil absorbing complex by exchange calcium. After introduction of the ameliorant, the content of calcium content in the soil by the end of rotation increased by $1.9 \mathrm{mmol} / 100 \mathrm{~g}$ of soil, on the sapropel background by $2.2-2.9 \mathrm{mmol} / 100 \mathrm{~g}$ of soil. The base saturation on these variants correspondingly amounted to $84.9 \%$ and $88.2 \%$.

The determination of various forms of acidity has demonstrated that cultivation of grain crops and mineral fertilization increases the fraction of exchange hydrogen and soil acidity.

Liming of chernozem has affected the hydrolytic acidity of soil (Ha). In 2016, Ha on the unfertilized variant equaled 3.82 $\mathrm{mmol} / 100 \mathrm{~g}$ of soil; treatment by sapropel 2 has increased its value up to $4.17 \mathrm{mmol} / 100 \mathrm{~g}$ of soil. The decrease of the acidity under the action of organic fertilizers has manifested the most after introduction of them with lime: up to $2.62 \mathrm{mmol} / 100 \mathrm{~g}$ of soil. Simultaneously, the introduction of mineral fertilizers increased the hydrolytic acidity of chernozem by 0.51 $\mathrm{mmol} / 100 \mathrm{~g}$ of soil (Table 4 ).

The reaction of soil solution $\left(\mathrm{pH}_{\mathrm{H} 2 \mathrm{O}}\right)$ for reference variant was 6.38 , while after organic fertilization this indicator decreased down to 6.26-6.36. The value of $\mathrm{pH}_{\mathrm{H} 2 \mathrm{O}}$ after nitrogen-phosphorus fertilizers decreased down to 6.23. The largest effect on the $\mathrm{pH}$ was made by lime where the value of actual acidity was 6.54 . The application of lime in combination with organic fertilizers increased the indicator up to 6.74-6.98.

The exchange acidity $\left(\mathrm{pH}_{\mathrm{KCl}}\right)$ for reference was 5.21, after introduction of mineral fertilizers it increased to 5.14. The liming of the soil reduced the exchange acidity down to 5.52 . For the background of sapropel 1, $\mathrm{pH}_{\mathrm{KCl}}$ was 6.00. Introduction of lime together with mineral fertilizers increased $\mathrm{pH}_{\mathrm{KCl}}$ by 0.13 .

Paired linear correlation analysis of agrochemical soil indicators in the end of crop rotation has not revealed their 
appreciable impact on barley yield (correlation coefficients were $0.01-0.10)$. Multiple non-linear correlation-regressive analysis has discovered provable impact of exchange acidity of soil and content of calcium cation on barley yield, which allowed building mathematical model (1) describing this dependence.

$$
\begin{gathered}
y=51.8785-38.6013 x_{1}+8.7069 x_{2}+7.995 x_{1}{ }^{2}- \\
-3.7872 x_{1} x_{2}+0.4637 x_{2}{ }^{2}
\end{gathered}
$$

where $\mathrm{y}$ is barley yield, $\mathrm{t} / \mathrm{ha}$;

$\mathrm{x}_{1}$ is $\mathrm{pH}_{\mathrm{KCl}}$;

$\mathrm{x}_{2}$ is the content of $\mathrm{Ca}^{2+}, \mathrm{mmol} / 100 \mathrm{~g}$ of soil.

The graphical representation of the model is given in Fig. 1.
According to model (1), the increase of calcium cation content and simultaneous increase of $\mathrm{pH}_{\mathrm{KCl}}$, the barley yield grows. At $\mathrm{pH}_{\mathrm{KCl}}$ of 4.8-5.4, the increased content of calcium cations promotes the growth of grain yield, while at $\mathrm{pH}_{\mathrm{KCl}}$ of 5.8-6.2 the increased content of calcium cations decreases the grain yield.

The input of experimental results of $\mathrm{pH}_{\mathrm{KCl}}, \mathrm{Ca}^{2+}$ cation content and barley yield into the suggested model (Table 5) has shown that of 12 observations, only 2 (17\%) cases of discrepancy between $Y_{\text {exp }}$ and $Y_{\text {calc }}$ exceeded 0.2 t/ha, which tells about comparatively high prognostication capabilities of the model.

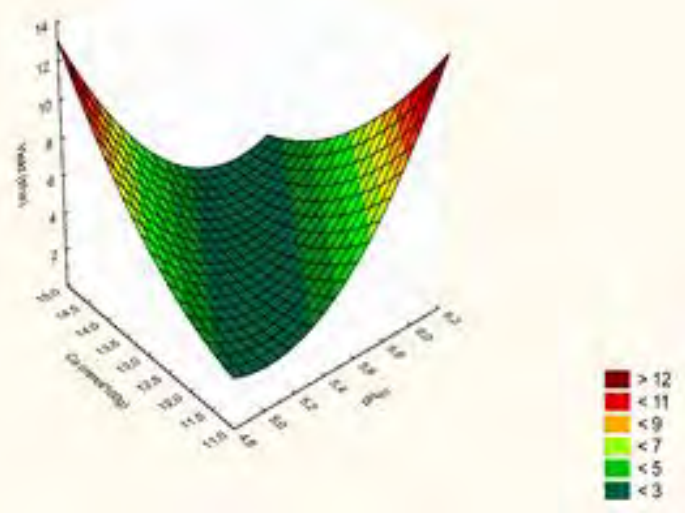

Fig I. Dependence of barley yield on $\mathrm{pH}_{\mathrm{KCl}}$ and content of calcium cations (2016)

\begin{tabular}{|c|c|c|c|c|c|}
\hline Variant & $\mathrm{pH}_{\mathrm{KCl}}\left(\mathrm{x}_{1}\right)$ & $\mathrm{Ca}^{2+}\left(\mathrm{x}_{2}\right)$ & $y\left(Y_{\exp }\right)$ & $\mathbf{y}\left(Y_{\text {calc }}\right)$ & $y\left(Y_{\text {exp }}\right)-y\left(Y_{\text {calc }}\right)$ \\
\hline 1. No fertilizers (reference) & 5.21 & 11.5 & 2.13 & 2.33 & -0.20 \\
\hline 2. Sapropel 1, $20 \mathrm{t} / \mathrm{ha}$ & 5.24 & 12.0 & 2.23 & 2.25 & -0.02 \\
\hline 3. Sapropel 2, $20 \mathrm{t} / \mathrm{ha}$ & 5.14 & 11.9 & 2.06 & 2.32 & -0.26 \\
\hline 4. N30P30 & 5.06 & 11.2 & 2.56 & 2.31 & 0.25 \\
\hline 5. N30P30 + sapropel 1, 20 t/ha & 5.09 & 12.0 & 2.64 & 2.47 & 0.17 \\
\hline 6. N30P30 + sapropel 2, $20 \mathrm{t} / \mathrm{ha}$ & 4.96 & 11.7 & 2.61 & 2.67 & -0.06 \\
\hline 7. Lime, $2 \mathrm{t} / \mathrm{ha}$ - background & 5.52 & 13.4 & 2.20 & 2.21 & -0.01 \\
\hline 8. Background + sapropel $1,20 \mathrm{t} / \mathrm{ha}$ & 6.00 & 14.4 & 2.37 & 2.41 & -0.04 \\
\hline 9. Background + sapropel 2, $20 \mathrm{t} / \mathrm{ha}$ & 5.54 & 13.7 & 2.33 & 2.28 & 0.05 \\
\hline 10 Background + N30P30 & 5.65 & 12.8 & 2.62 & 2.53 & 0.09 \\
\hline 11. Background + N30P30 + sapropel 1, 20 t/ha & 5.45 & 13.9 & 2.60 & 2.69 & -0.09 \\
\hline 12. Background $+\mathrm{N} 30 \mathrm{P} 30+$ sapropel 2, $20 \mathrm{t} / \mathrm{ha}$ & 5.42 & 13.5 & 2.59 & 2.47 & 0.12 \\
\hline
\end{tabular}

TABLE 5. VALIDATION OF PROGNOSTICATION CAPABILITIES OF THE MODEL

\section{CONCLUSIONS}

1. Annual application of mineral fertilizers has increased the grain crops yield by $17 \%$, organic fertilizers has increased it by $3-6 \%$, while the combined application of lime, sapropel and nitrogen-phosphorous fertilizer by $18-22 \%$

2. The application of the fertilizers for grain crops seeding has increased the grain quality. The results demonstrate average direct positive correlation of the mass of 1000 grains with crops yield $(\mathrm{r}=0.63-0.89)$.

3. The application of mineral fertilizers led to acidification of soil and deterioration of agrochemical chernozem indicators. The introduction of lime and sapropel 1 led to decreased acidity of all forms and saturation of SAC by calcium. 


\section{References}

[1] T.T. Brown, R.T. Koenig, J.B. Harsh, D.R. Huggins, R.E. Rossi, "Lime effects on soil acidity, crop yield, and aluminum chemistry in directseeded cropping systems", Soil science society of America journal, vol. 72, No. 3, 2008, pp. 634-640, DOI: 10.2136/sssaj2007.0061.

[2] E.F. Caires, A. Haliski, A.R. Bini, D.A.Scharr, "Surface liming and nitrogen fertilization for crop grain production under no-till management in Brazil", European journal of agronomy, vol. 66, 2015, pp. 41-53, DOI: 10.1016/j.eja.2015.02.008.

[3] V.G. Mineev, N.F. Gomonova, "The impact of soil liming on the background of the long-term action and aftereffect of fertilizers on physicochemical properties of soddy-podzolic soil", Eurasian soil science vol. 34, No. 9, 2001, pp. 985-992.

[4] S.M. Shtin, "Lacustrine sapropels and their comprehensive development" (in Russian), I.M. Yaltantsa, Eds. Moscow: Press of Moscow State Mining University, 2005, p. 373.

[5] A.A. Vasilyev, "Impact of sapropels on potato yield and fertility of leached chernozems" (in Russian), Perm agrarian bulletin, 2014, vol. 5, No. 1, pp. 3-9.

[6] V.D. Pannikov, V.G Mineev, "Soil, climate, fertilizers and crops" (in Russian), Moscow: Agropromizdat, 1987, p. 512.

[7] G.P. Gamzikov, O.I. Gamzikov, P.S. Shirokikh, "Perspectives of nonconventional fertilizers in arable farming in Siberia" (in Russian), Achievements of science and engineering of AIC, 2012, No. 3, pp. 9-12.
[8] A.V. Vrazhnov, Yu.D. Kushnirenko, V.N. Bragin, Kh.S. Yumashev, "Organic fertilizers and their practical application in Chelyabinsk region" (in Russian), Agrarian bulletin of Urals, 2008, vol. 51, No. 9, pp. 50-54.

[9] "Study and economical application of peat and sapropel resources" (in Russian), Proc. Int. Symp. in Tyumen on 18-20 June, Abramov N.V., Eds. 2006 [Tyumen: Press of Tyumen SAA, 2006, p. 324]

[10] P.S. Dmitriev, E.A. Fomin, E.R. Aytzhanov, "Perspectives of application in North Kazakhstan of fertilizers made from local cheese" (in Russian), Urgent problems of humanitarian and natural sciences, 2014, No. 4-1, pp. 123-128.

[11] V.G. Mineev, "Practical course in agrochemistry: Learning guide" (in Russian), V.G. Mineeva, Eds. Moscow: MSU Press, 2001, p. 689.

[12] B.A. Dospekhov, "Methods of field experiments" (in Russian), Moscow: Agropromizdat, 1985, p. 351.

[13] "System for adaptive-landscape arable farming in Kurgan region, monograph" (in Russian), Kurtamysh, Russia: SUE Kurtamyshskaya tipografiya, 2012, p. 494.

[14] A.M. Plotnikov, A.V. Sozinov, S.V. Degtyaryov, "Wheat yield and grain quality after using sapropel in the central part of Kurgan region" (in Russian), Bulletin of Kurgan SAA, 2014, vol. 12, No. 4, pp. 27-29.

[15] A.M. Plotnikov, A.V. Sozinov, "Impact of sapropels on grain crops yield and acidity of leached chernozem" (in Russian), International scientific and research journal, 2016, vol. 46, No. 4, part 6, pp. 61-65. 